\title{
Combination of graphene and graphene oxide with metal and metal oxide nanoparticles in fabrication of electrochemical enzymatic biosensors
}

\author{
Fatemeh Parnianchi ${ }^{1} \cdot$ Maryam Nazari $^{1,2} \cdot$ Jila Maleki $^{3} \cdot$ Marjan Mohebi $^{4}$
}

Received: 9 June 2017 / Accepted: 17 October 2018 / Published online: 27 October 2018

(C) The Author(s) 2018

\begin{abstract}
At present, graphene has been widely utilized in electronics, electric devices, and biosensors. As its unparalleled properties including high surface area, excellent conductivity, ease of functionalization, and production, graphene provides an ideal platform to make useful nanomaterials, and motivates researchers to synthesize metallic nanoparticles-graphene nanocomposites for fabricating of sensors and biosensors. Fabrication of metallic nanoparticle-graphene nanohybrids and their application in sensing systems allows greatly sensitive, selective, stable, and fast electrochemical sensing of analytes. This review presents the recent studies in the construction of metallic nanoparticles graphene or graphene oxide composite-based electrochemical biosensors. It discusses the application of metallic nanomaterials to the assembly of graphene- and graphene oxide-based electrochemical enzymatic biosensors and its analytical performance.
\end{abstract}

Keywords Biosensor $\cdot$ Graphene $\cdot$ Graphene oxide $\cdot$ Metallic nanoparticles

\section{Introduction}

Recently, the development of an electrochemical basis for considerations of structure, redox transformation mechanisms, and metabolic processes involving redox transformations of protein molecules has been paid increasingly attention. For the development of electrochemical biosensing

Fatemeh Parnianchi

fatemehparnianchi@yahoo.com

$\triangle$ Maryam Nazari

nazari.maryam@razi.ac.ir

Jila Maleki

Jina_maleki@yahoo.com

Marjan Mohebi

marjan.mohebi@yahoo.com

1 Faculty of Chemistry, Razi University, Kermanshah, Iran

2 Nano Drug Delivery Research Center, Faculty of Pharmacy, Kermanshah University of Medical Sciences, Kermanshah, Iran

3 Department of Chemistry, Faculty of Science, University of Bu-Ali-Sina, Hamadan, Iran

4 Faculty of Pharmacy, Kermanshah University of Medical Sciences, Kermanshah, Iran system, understanding of these informations is needed because of providing the insight into electron transfer of physiological process $[1,2]$. To achieve the direct electron transfer among enzymes and electrodes is of great importance in the creation of mediator-free electrochemical biosensors [3,4]. Because of the enzymes, redox-active center is surrounded by its protein shell deeply, and therefore, the direct electron transferring between the protein center and the electrode surface is generally not simple [5]. Moreover, the enzyme maybe loses its bioactivity when it adsorbed directly onto the electrode surface [6, 7]. These problems make cause to be difficult electron transferring at the traditional electrodes. The important factor in biosensor fabrication is the enzyme immobilization using nanomaterials to maintain bioactivity [8]. Using nanomaterials in immobilizing process of enzymes makes to increase the electron transferring and biocatalytic activity $[1,9,10]$. Therefore, employing nanomaterials is an efficient manner to enable the direct electron transfer and protect immobilized enzymes from losing their activity [11]. Among nanomaterials, twodimensional layered nanomaterials, such as graphene (GR), have appealed widespread attention to being utilized for the immobilization of enzymes onto electrode surface, due to specific properties such as large enough surface areas, excellent electronic transport, and good biocompatibility [12]. 
Carbon is a significant material used as solid electrodes. $\mathrm{GR}$, with a two-dimensional sheet of $\mathrm{sp}^{2}$-bonded carbon, is one of the suitable forms of material due to its remarkable features [13, 14]. It possesses large interfacial surface area much better than carbon nanotubes (CNTs) and it is as a good substitute for CNTs due to providing a cost-effective platform for creation combination materials containing GR and metal nanoparticles [15]. The modification of electrodes by electrically conductive, cost-effective GR is promising for developing biosensors, since GR can create a favorable microenvironment for enzyme and promote a direct electron transferring of enzyme at the electrodes surface. GR and its oxide form might promise the development of less expensive and more efficient biosensors in future [16]. However, more efforts are under way to translate the research results of the laboratory to the field applications to assess the potential of GR employing for enormous scale usage in near future [17].

In addition, various metal nanoparticles have been applied as the effective immobilization scaffolds for the improvement of highly sensitive electrochemical biosensors [18, 19]. They have demonstrated great capability to stimulate direct electron transferring of the entrapped biomolecules and keeping their bioactivity in a long time.

This review investigates the combination of GR and metal nanoparticles for recently enzymatic biosensors and the results of them are collected in tables for more convenient investigations.

\section{Graphene and graphene oxide properties and applications}

GR is composed of carbon atoms as a single layer that is bonded to each other by a $\mathrm{sp}^{2}$ hybridization and creates a honeycomb lattice [20]. The excellent properties of GR are associated with its single layer and cause to tremendous attention from the experimental and the theoretical scientific communities in the recent years [21].

GR has shown great potential as sensing element due to its unique advantages such as tremendous electrical conductivity, large surface area, fast electron transportation, ease of functionalization, and mass production [22-24]. Therefore, every atom in GR sheets is a surface atom and has molecular interaction, and thus electron transport through GR can be highly sensitive to absorbed molecules [25-27]. This material shows superior electrical, mechanical, thermal, and catalytic properties that are suitable for use in sensors [28], Li-ion batteries [29], nanofluids [30], nanocomposites, and biotechnology [31]. It holds great potential for use in many technological fields such as, electronics [32], supercapacitors [33], batteries [34], fuel cells [35], and solar cells [36]. The combination of GR with metallic nanoparticles into electrochemical biosensors has, indeed, resulted in dramatic evolution of various organic compounds detection such as phenolic compound [37], dopamine [38], $\mathrm{H}_{2} \mathrm{O}_{2}$ [39], glucose [40], NADH [41], uric acid, and ascorbic acid [42].

Usually, oxidizing graphite powder with some strong oxidants and exfoliating forms graphene oxide (GO) and it can be reduced for preparing GR [43]. Single atomic layer of GO is covered with hydroxyl, epoxy, carbonyl, and carboxyl groups [44]. Nanocomposites, antibacterial paper, chemically modified GR and GO, in conjugate with proteins can be prepared [45]. Because GO bears abundant oxygen-containing functional groups, it is dispersible in aqueous solution [46]. Several methods have been successfully developed to prepare GR with a single layer, such as the scotch tape [47], chemical vapor deposition [48], epitaxial growth on electrically insulating and conducting surface and chemical oxidation-reduction of graphite [49]. The solvent phase oxidation-reduction method has attracted significant interest due to its potential use for mass production. It has ability to easily functionalize of the GR surface for different applications [50]. Commonly, GR is dispersed in solvent or polymer solutions (such as chitosan and nafion solutions) and then it is used for modifying of electrode surfaces [51]. In addition, electrochemical polymerization has also been applied to modify GR on the electrode surface [52]. The mixtures of GR with the prepolymers of urea and formaldehyde, styrene, or methyl acrylate were prepared [53]. The GR containing mixtures would cure to form GR-polymer composite sensors [54]. It has been confirmed by many research groups that electrically conductive GR showed strong electrocatalytic activity when it was employed to improve the electrochemical response of some bioactive substances [22].

To diminish the agglomeration of GR sheets, surface modification of GO prior to reduction is essential $[55,56]$. Chemical functionalization of GR using foreign stabilizer, such as small organic molecules, low-molecular weight polymers, or small biomolecules, can increase the dispersibility in organic or aqueous solvents $[57,58]$. The chemical moiety attached to the GR surface by non-covalent or covalent bonds generally increases the hydrophilic or organophilic character of the GR and promotes dispersion in the selected solvent.

\section{The hybridizing of GR and $\mathrm{GO}$ with metallic nanoparticles}

Nanostructures have high surface area-to-volume ratios and can increase the voltammetric responses in case of electroactive analytes that can transfer from the solution to the electrode surface. The hybridization of GR (or its derivatives) with functional nanomaterials might enhance the functional properties of components, and create new properties via cooperative interaction. Nanoscale is extremely important 
for developing composite-based biosensors due to nanoparticles propertied such as much lower particle-particle distance, larger surface/volume ratio, and the ability to create stronger adsorption than their peer micron-sized particles. In addition, materials in nanoscale have unique photonic, electronic, magnetic, electrocatalytic, and biosensing properties, which have been recently exploited successfully [59]. Using the combination of metal nanoparticles upon reduced graphene oxide (RGO) sheets causes to separate the individual sheets and also allows heterogeneous catalytic processes [60]. The dispersion of metallic nanoparticles on GR sheets makes new ways in designing of hybrid materials for various applications.

In recent years, the numbers of researches in biosensing applications have been appropriated to the hybrid of GR with metallic nanoparticles such as gold nanoparticles (AuNPs), magnetic nanoparticles, nickel nanoparticles (NiNPs), cupper nanoparticles (CuNPs), and palladium nanoparticles (PdNPs) in electrochemical biosensors.

\section{Gold nanoparticle}

Gold is an interesting coating material due to simple synthetic methods and its chemical functionality. AuNPs are one of the maximum considered nanomaterials because of their remarkable properties. They have great properties such as large specific surface area, high electrochemical catalytic activity, strong adsorption ability, biocompatibility, well suitability, and high conductivity [61]. AuNPs have been employed to synthesize different types of electrochemical and also optical sensors successfully [62-66]. They can strongly interact with biomaterials, and have been employed as intermediators to immobilize enzyme [67], protein [68], aptamer [69], and antibody [70] to enhance the current response in the creation of a sensitive electrochemical biosensors. Therefore, it attracts much attention in constructing electrical sensors such as enzymes biosensors, DNA-AuNPs assemblies, and immunosensors. A common, simple, and rapid method for making AuNPs is electrodeposition [71]. It enables concomitance fine-tuning and fast reaction of nanomaterial systems to changes in deposition conditions [72].

The AuNPs-GR hybrid materials exhibit favorable electrochemical properties and they are worth to explore their applications in various fields. Based on the unique properties of AuNPs and GR, considerable endeavors have been allocated to incorporation Au nanoparticles into GR matrix. The fabrication of AuNPs and GR sheets' composites conduct through two main methods. The first method, using layer-by-layer strategy, includes using an intermediate as linker, between AuNPs and GR [73, 74]. A major disadvantage in this method is decreasing in conductivity of composite because of the presence of insulting materials. In the second method, the synthesis of GR-AuNPs' composite is done through the co-reduction of $\mathrm{GO}$ and $\mathrm{Au}$ salt. There are some limitations to the second method, which are still challenging that the mains of them are difficulties to homogeneous distribution of nanoparticles, controllable AuNPs morphology, controllable reduction route, and a significant problem is absence of good processability. Low processability occurs, since the resulting composite yield in the form of precipitate and biosensing applications requires dispersed materials. The intercalation of metal nanoparticles between reduced GO sheets may not be happened in the above-mentioned approaches [73]. However, the stability of GO in the existence of special ionic strength is still under investigation. In the previous researches, Au-RGO nanocomposites were synthesized either by employing covering substances (surfactants) or extra reducing agents [75] or without using any other reducing agents, capping reagents, stabilizers, or surfactants [76]. Up to now, in comparing to the other metallic nanoparticles, many studies have done in the research of mixtures containing GR and AuNPs through the various functionalization strategies with potential applications in enzymatic biosensor (Table 1).

\section{Titanium oxide nanoparticle}

$\mathrm{TiO}_{2}$ is n-type, wide band-gap semiconductor with good stability, biocompatibility, and environmentally friendly properties [86]. First, due to the great surface area of $\mathrm{TiO}_{2}$ nanomaterials, they have inimitable electronic, optical, photocatalytic, chemical, and physical properties, non-toxic and environmentally friendly nature, excellent biocompatibility, and stability $[87,88]$. Second, an enormous amount of the $\mathrm{TiO}_{2}$ nanostructures was manufactured, characterized, and accessible for sensor fabrication owing to the tremendous endeavors from scientists and materials engineers. Owing to its high conductivity and low cost, $\mathrm{TiO}_{2}$ is an attractive electrode material in different forms such as nanoparticles, nanoneedles, nanofibers, nanosheets, and nanotubes [89-92]. By combining modern technologies, such as microfabrication technology (e.g., lab-on-chip fabrication), and microelectronic devices, $\mathrm{TiO}_{2}$ nanomaterials will be widely used construct efficient, low cost, environmental benign sensors for detecting chemicals in aqueous media. They can be decorated on GR or other carbon material to fabricate electrochemical-based biosensors [29]. Using $\mathrm{GR}-\mathrm{TiO}_{2}$ nanocomposites has several benefits such as high conductivity to electron transferring plus more active sites for the immobilization of enzymes. In addition, the presence of nanocomposites such as $\mathrm{GO}$ and $\mathrm{TiO}_{2}$ can increase the active sites and the electron transfer reactions [93]. Using $\mathrm{GO}$ and $\mathrm{TiO}_{2}$ together was applied for the construction of electrochemical sensors [94], electrochemical biosensors [95, 96], photocatalytic [97-99], and photoelectrocatalytic [8] applications. $\mathrm{TiO}_{2}$ acts as an effectual agent in biosensing applications 
Table 1 AuNPs-GR-based electrochemical enzymatic biosensors

\begin{tabular}{|c|c|c|c|c|c|c|c|c|}
\hline $\begin{array}{l}\text { Biosensor } \\
\text { structure }\end{array}$ & $\begin{array}{l}\text { Type of } \\
\text { metallic } \\
\text { nanoparticle }\end{array}$ & $\begin{array}{l}\text { Used } \\
\text { enzyme or } \\
\text { protein }\end{array}$ & Analyte & Linear range $(\mathrm{M})$ & LOD (M) & Sensitivity & $\begin{array}{l}\text { Stability } \\
\text { (days) }\end{array}$ & References \\
\hline $\begin{array}{l}\text { AuNPs/GR/ } \\
\text { HRP/Chit/ } \\
\text { GCE }\end{array}$ & AuNPs & HRP & $\mathrm{H}_{2} \mathrm{O}_{2}$ & $\begin{array}{l}5 \times 10^{-6}- \\
5.13 \times 10^{-3}\end{array}$ & $1.7 \times 10^{-6}$ & - & 21 & [77] \\
\hline $\begin{array}{l}\text { PANI/HRP/ } \\
\text { GR-CNT- } \\
\text { Nafion/AuPt } \\
\text { NPs/GCE }\end{array}$ & AuPtNPt & HRP & $\mathrm{H}_{2} \mathrm{O}_{2}$ & $\begin{array}{r}5.0 \times 10^{-7}- \\
1.0 \times 10^{-4}\end{array}$ & $1.7 \times 10^{-7}$ & $3.7 \times 10^{2} \mu \mathrm{A} \mathrm{mM} M^{-1}$ & 30 & [78] \\
\hline $\begin{array}{l}\text { HRP/AuNPs/ } \\
\text { CdTe-CdS/ } \\
\text { GR-AuNP/ } \\
\text { AuE }\end{array}$ & AuNPs & HRP & $\mathrm{H}_{2} \mathrm{O}_{2}$ & $1 \times 10^{-10}-1.2 \times 10^{-8}$ & $3.2 \times 10^{-11}$ & - & 140 & [79] \\
\hline $\begin{array}{l}\mathrm{Hb} / \text { AuNPs/ } \\
\text { GR-Chit/ } \\
\text { GCE }\end{array}$ & AuNPs & $\mathrm{Hb}$ & $\mathrm{H}_{2} \mathrm{O}_{2}$ & $\begin{array}{l}2 \times 10^{-6}- \\
935 \times 10^{-6}\end{array}$ & $0.35 \times 10^{-6}$ & $347.1 \mathrm{~mA} \mathrm{~cm}^{-2} \mathrm{M}^{-1}$ & 30 & [8] \\
\hline $\begin{array}{l}\text { GR/AuNPs/ } \\
\text { GOD/Chit } \\
\text { film-AuE }\end{array}$ & AuNPs & GOD & Glucose & $2 \times 10^{-4}-4.2 \times 10^{-3}$ & $180 \times 10^{-6}$ & $99.5 \mu \mathrm{A} \mathrm{mM}^{-1} \mathrm{~cm}^{-2}$ & 15 & {$[80]$} \\
\hline $\begin{array}{l}\text { PRGO-AuNPs/ } \\
\text { GOD/GCE }\end{array}$ & AuNPs & GOD & Glucose & $0.4 \times 10^{-6}-4 \times 10^{-6}$ & $0.06 \times 10^{-6}$ & $15.04 \mathrm{mAmM}^{-1}$ & 14 & [73] \\
\hline $\begin{array}{l}\text { GR-AuNPs/ } \\
\text { GOD/GCE }\end{array}$ & / AuNPs & GOD & Glucose & $\begin{array}{l}0.2 \times 10^{-3}-2 \times 10^{-3} \\
\text { and } 2 \times 10^{-3}- \\
20 \times 10^{-3}\end{array}$ & $17 \times 10^{-6}$ & $\begin{array}{l}56.93 \text { and } 13.48 \mu \mathrm{A} \\
\mathrm{mM}^{-1} \mathrm{~cm}^{-2}\end{array}$ & 14 & [15] \\
\hline $\begin{array}{l}\text { GOD-GR/ } \\
\text { PANI/AuNPs } \\
\text { GCE }\end{array}$ & AuNPs & GOD & Glucose & $\begin{array}{l}4.0 \times 10^{-6}- \\
1.12 \times 10^{-3}\end{array}$ & $0.6 \times 10^{-6}$ & & 20 & [81] \\
\hline $\begin{array}{l}\text { GOD/Chit- } \\
\text { RGO-AuNPs/ } \\
\text { PtE }\end{array}$ & AuNPs & GOD & Glucose & $\begin{array}{l}15 \times 10^{-6}- \\
2.13 \times 10^{-3}\end{array}$ & $1.7 \times 10^{-6}$ & $\begin{array}{l}102.4 \mu \mathrm{A} \mathrm{mM} \\
\mathrm{cm}^{-2}\end{array}$ & 30 & {$[82]$} \\
\hline $\begin{array}{l}\text { Lac-Tyr- } \\
\text { AuNPs-Chit/ } \\
\text { GPE }\end{array}$ & AuNPs & Lac and Tyr & $\begin{array}{l}\text { Carbaril } \\
\text { Formetanate } \\
\text { Propoxur } \\
\text { Ziram }\end{array}$ & $\begin{array}{c}9.90 \times 10^{-8}- \\
2.91 \times 10^{-6} \\
9.99 \times 10^{-7}- \\
3.21 \times 10^{-5} \\
4.99 \times 10^{-7}- \\
1.92 \times 10^{-5} \\
9.99 \times 10^{-8}- \\
3.38 \times 10^{-7}\end{array}$ & $\begin{array}{l}1.98 \times 10^{-8} \\
2.15 \times 10^{-7} \\
1.87 \times 10^{-7} \\
1.68 \times 10^{-9}\end{array}$ & - & 20 & [83] \\
\hline $\begin{array}{l}\text { GR/AuNPs- } \\
\text { Tyr-Chit/ } \\
\text { GCE }\end{array}$ & AuNPs & Tyr & Bisphenol A & $\begin{array}{l}2.5 \times 10^{-9}- \\
3.0 \times 10^{-6}\end{array}$ & $1 \times 10^{-9}$ & $3.597 \mathrm{~mA} \mathrm{mM}^{-1}$ & 90 & {$[84]$} \\
\hline $\begin{array}{l}\text { AChE/AuNPs- } \\
\text { PPy-RGO/ } \\
\text { GCE }\end{array}$ & AuNPs & $\mathrm{AChE}$ & $\begin{array}{l}\text { Paraoxon- } \\
\text { ethyl }\end{array}$ & $1.0 \times 10^{-9}-5 \times 10^{-6}$ & $0.5 \times 10^{-9}$ & - & - & {$[52]$} \\
\hline $\begin{array}{l}\text { Chit/AChE/ } \\
\text { PB-Chit/ } \\
\text { ERGO- } \\
\text { AuNPs- } \\
\beta-C D / G C E\end{array}$ & AuNPs & $\mathrm{AChE}$ & $\begin{array}{l}\text { Malathion } \\
\text { Carbaryl }\end{array}$ & $\begin{array}{l}7.98-2000 \mathrm{pg} \mathrm{mL}^{-1} \\
4.3-1000 \mathrm{~b} \mathrm{pg} \mathrm{mL}-1\end{array}$ & $\begin{array}{l}4.14 \mathrm{pg} \mathrm{mL}^{-1} \\
1.15 \mathrm{pg} \mathrm{mL}^{-1}\end{array}$ & $\begin{array}{l}14.5 \mu \mathrm{A} \mathrm{mM} M^{-1} \\
9.51 \mu \mathrm{Am}^{-1}\end{array}$ & 28 & {$[85]$} \\
\hline
\end{tabular}

$H b$ hemoglobin, Chit Chitosan, GOD glucose oxidase, Lac laccase, Tyr tyrosinase, GPE graphene-doped carbon paste electrode, ERGO electrochemical reduced graphene oxide, $P B$ Prussian blue-chitosan, $\beta$ - $C D \beta$-cyclodextrin, AChE acetylcholinesterase, $P R G$ partially reduced graphene, PPy polypyrrole 
owing to its high reactivity, specific affinity to biomolecules, and good biocompatibility. In Table $2 \mathrm{TiO}_{2}$-based electrochemical enzymatic biosensors are shown.

\section{Ferrous nanoparticle}

Ferrous nanoparticles $\left(\mathrm{Fe}_{3} \mathrm{O}_{4} \mathrm{NPs}\right)$ are a type of magnetic materials with high attention due to their low toxicity, paramagnetic property, good biocompatibility, easy preparation [101], and, more notably, the close contact among the nanoparticles, substrates, and biocatalyst [102]. In recent years, $\mathrm{Fe}_{3} \mathrm{O}_{4} \mathrm{NPs}$ have appealed widespread consideration for their potential applications in ferrofluids [103], rechargeable batteries [104], magnetic resonance imaging [105], targeted drug delivery $[52,106]$, and catalysis [107]. In addition, $\mathrm{Fe}_{3} \mathrm{O}_{4} \mathrm{NPs}$ have been commonly utilized for biosensing and the electrodes reforming, because they enhance the electrode surface, electrical conductivity, and electron transfer kinetics among the electrode surface and many electroactive species [108]. $\mathrm{Fe}_{3} \mathrm{O}_{4} \mathrm{NPs}$ are considered as an effective carrier for the immobilization of desired biomolecules for biosensing [109]. Agglomeration prevents $\mathrm{Fe}_{3} \mathrm{O}_{4} \mathrm{NPs}$ to immobilize proteins and enzymes. An important factor in biosensor fabrication is to uniformly disperse $\mathrm{Fe}_{3} \mathrm{O}_{4} \mathrm{NPs}$ in a suitable matrix such as chitosan, carbon, and GR to prevent agglomeration [110]. It is of great interest to modify electrodes with the combination of GR with magnetic $\mathrm{Fe}_{3} \mathrm{O}_{4}$ particles for constructing novel biosensors. Recently, $\mathrm{Fe}_{3} \mathrm{O}_{4} /$ GR composites have been prepared for immobilizing HRP to construct a mediator-free $\mathrm{H}_{2} \mathrm{O}_{2}$ biosensor with the $\mathrm{Fe}_{3} \mathrm{O}_{4}$ particles size of 200-250 nm in diameter. The $\mathrm{Fe}_{3} \mathrm{O}_{4} / \mathrm{GR}$ composite can be synthesized by in situ reduction of microwave heating of ferric hydroxide. This method has some disadvantages; large particle sizes, and poor particle dispersion, and thus, special treatments or equipment are necessary [111]. To fabricate the uniformly dispersed $\mathrm{Fe}_{3} \mathrm{O}_{4} \mathrm{NPs}$ on GR sheets, a method was reported, which can disperse $\mathrm{Fe}_{3} \mathrm{O}_{4}$ NPs of $10 \mathrm{~nm}$ in diameter on the RGO sheet [112]. In this method, a mixture of $\mathrm{Fe}_{3} \mathrm{O}_{4} \mathrm{NPs}$ and $\mathrm{GO}$ was obtained and then baked under inert atmosphere to fabricate a nanocomposite. Because of absenting of TEM investigations, it is not clear whether these nanoparticles were uniformly dispersed or aggregated.

Well-known procedures for $\mathrm{Fe}_{3} \mathrm{O}_{4} \mathrm{NPs}$ fabrication in smaller size onto RGO mostly consist of (1) chemical method; the $\mathrm{Fe}_{3} \mathrm{O}_{4} \mathrm{NPs}$ are deposited onto GO through controlling of $\mathrm{pH}$, ion exchange, dialysis, and precipitation, (2) conjugation chemistry, and (3) assembly examination and controlling of $\mathrm{Fe}_{3} \mathrm{O}_{4} \mathrm{NPs}$ on GO. The disadvantages of these procedures are being complicated due to their multi-step procedures and using expensive raw materials [110]. Therefore, major challenges are cost-effectively fabricating and manipulating these nanoparticles onto GR surface to achieve a uniform dispersion. Some of enzymatic biosensors that used GR and magnetic nanoparticles are shown in Table 3.

\section{Nickel nanoparticle}

Nickel oxide $(\mathrm{NiO})$ nanostructures-based materials have been extensively applied in supercapacitor and electrochemical sensors, particularly in non-enzymatic glucose sensing owing to their tremendous electrocatalytic and inexpensive properties. Ni-based nanomaterials have catalytic oxidation activity for the glucose oxidizing owing to the catalytic influence of the redox couple of $\mathrm{Ni}(\mathrm{II}) / \mathrm{Ni}(\mathrm{III})$ formation on the electrode surface in alkaline medium [115] and the most Ni-based non-enzymatic sensors are fabricated for glucose detection. Various morphological Ni nanostructures have been manufactured by different methods in past decades. Nickel oxide and hydroxide have great interest for biosensing development due to their properties including biocompatibility, cost effectiveness, nontoxicity, high chemical stability, and high electrocatalytic effect [116]. Owing to the exclusive properties of $\mathrm{NiO}$ nanostructures, they could be applied for the immobilization of diverse molecules and biomolecules to construct sensors and biosensors [117]. Some researchers have investigated the electrocatalytic effect of GR-NiO-enzyme or biomolecules modified electrodes towards the electroredox reaction of $\mathrm{H}_{2} \mathrm{O}_{2}$ and pesticides. These biosensors are shown in Table 4 . These biosensors have very low

Table $2 \mathrm{TiO}_{2}$-GR-based electrochemical enzymatic biosensors

\begin{tabular}{|c|c|c|c|c|c|c|c|c|}
\hline Biosensor structure & Type of nanoparticle & $\begin{array}{l}\text { Used } \\
\text { enzyme or } \\
\text { protein }\end{array}$ & Analyte & Linear range $(\mathrm{M})$ & LOD (M) & Sensitivity & $\begin{array}{l}\text { Stabil- } \\
\text { ity } \\
\text { (days) }\end{array}$ & References \\
\hline $\begin{array}{l}\mathrm{Hb} \text { in Chit-[bmim] } \mathrm{PF}_{6^{-}} \\
\mathrm{TiO}_{2}-\mathrm{GR} / \mathrm{GCE}\end{array}$ & $\begin{array}{l}\mathrm{TiO}_{2} \text {-GR nanocom- } \\
\text { posite }\end{array}$ & $\mathrm{Hb}$ & $\mathrm{H}_{2} \mathrm{O}_{2}$ & $1 \times 10^{-6}-1170 \times 10^{-6}$ & $0.3 \times 10^{-6}$ & - & 20 & {$[100]$} \\
\hline $\begin{array}{l}\text { PANI-TNTs/[Demim] } \\
\text { Br/Nafion/GOD/GCE }\end{array}$ & $\mathrm{TiO}_{2}$ nanotube & GOD & Glucose & $10 \times 10^{-6}-2.500 \times 10^{-3}$ & $0.5 \times 10^{-6}$ & $\begin{array}{l}177.16 \mu \mathrm{A} \\
\mathrm{mM}^{-1} \\
\mathrm{~cm}^{-2}\end{array}$ & 30 & [96] \\
\hline
\end{tabular}

1-Butyl-3-methylimidazolium hexafluorophosphate; [bmim]PF6, polyaniline; PANI, $\mathrm{TiO}_{2}$ nanotube; TNT, ionic liquid:brominated 1-decyl3-methyl imidazole; [Demim]Br 
Table $3 \mathrm{Fe}_{3} \mathrm{O}_{4}$-GR-based electrochemical enzymatic biosensors

\begin{tabular}{|c|c|c|c|c|c|c|c|c|}
\hline $\begin{array}{l}\text { Biosensor struc- } \\
\text { ture }\end{array}$ & $\begin{array}{l}\text { Type of metallic } \\
\text { nanoparticle }\end{array}$ & $\begin{array}{l}\text { Used } \\
\text { enzyme or } \\
\text { protein }\end{array}$ & Analyte & Linear range $(\mathrm{M})$ & $\operatorname{LOD}(\mathrm{M})$ & Sensitivity & Stability (days) & References \\
\hline $\begin{array}{l}\text { HRP-Au- }-\mathrm{Fe}_{3} \mathrm{O}_{4} / \\
\text { GS-Nafion/ } \\
\text { SPCE }\end{array}$ & $\mathrm{Fe}_{3} \mathrm{O}_{4}-\mathrm{AuNPs}$ & HRP & $\mathrm{H}_{2} \mathrm{O}_{2}$ & $2.0 \times 10^{-5}-2.5 \times 10^{-3}$ & $1.2 \times 10^{-5}$ & - & 30 & [113] \\
\hline $\begin{array}{l}\mathrm{Fe}_{3} \mathrm{O}_{4} / \mathrm{RGO} / \mathrm{Hb} / \\
\mathrm{GCE}\end{array}$ & $\mathrm{Fe}_{3} \mathrm{O}_{4} \mathrm{NPs}$ & $\mathrm{Hb}$ & $\mathrm{H}_{2} \mathrm{O}_{2}$ & $4 \times 10^{-6}-1 \times 10^{-3}$ & $2 \times 10^{-6}$ & $0.0468 \mu \mathrm{A} \mu \mathrm{M}^{-1}$ & - & [110] \\
\hline $\begin{array}{l}\mathrm{LDH} / \mathrm{Fe}_{3} \mathrm{O}_{4} / \\
\mathrm{RGO} / \mathrm{GCE}\end{array}$ & $\mathrm{Fe}_{3} \mathrm{O}_{4} \mathrm{NPs}$ & $\mathrm{LDH}$ & Lactate & $\begin{array}{l}1.5 \times 10^{-5} 1.9 \times 10^{-4} \\
2 \times 10^{-4}-2.2 \times 10^{-3}\end{array}$ & $-\overline{2} \times 10^{-5}$ & $\begin{array}{l}0.034 \mathrm{~A} \mathrm{M}^{-1} \\
\mathrm{~cm}^{-2} \\
0.0226 \mathrm{~A} \mathrm{M}^{-1} \\
\mathrm{~cm}^{-2}\end{array}$ & & [114] \\
\hline
\end{tabular}

SPCE screen-printed carbon electrode, $G S$ graphene sheets, $L D H$ lactate dehydrogenase

detection limits compared to the other biosensing systems of these analytes. Sun et al. used ionic liquid, GR, and in situ electrodeposited $\mathrm{NiO}$ step by step. After dropping of myoglobin $(\mathrm{Mb})$ solution on the electrode, they used nafion for the prevention of its leakage from the electrode surface [118]. In another work, Yang et al. fabricated an amperometric biosensor based on carboxylic graphene (CGR), NiO NPs (NiO nanoparticles), and nafion for the immobilization of acetylcholinesterase (AChE). For the preparation of NiO NPs-CGR composite, they added CGR to $\mathrm{Ni}\left(\mathrm{NO}_{3}\right)_{2}$ solution and mixed it using sonicator bath. Ethanol, sodium citrate, and deionized water and then ice-cold $\mathrm{NaBH}_{4}$ solution were added to this mixture and stirred. They separated the black suspending liquid using centrifuging, washed, and dried in an oven at $60{ }^{\circ} \mathrm{C}$. For the oxidation of Ni NPs, the product was heated at $120^{\circ} \mathrm{C}$ in atmosphere.

\section{Copper nanoparticle}

Copper nanoparticles (CuNPs) enhance the response current and they have good biocompatibility and relatively inexpensive cost [120]. $\mathrm{Cu}$ and $\mathrm{Cu}$ oxides are one of the compounds that have considerable attention in two application fields, fundamental research and technical. An increasing interest exists in the controllable production of inorganic micro/ nanostructures because of their special geometries, unique properties, and wide applications. The GR-CuNPs hybrids were prepared by encapsulating CuNPs with graphene. In another method, GR-CuNPs hybrids were developed by depositing GR layers onto CuNPs on a huge scale based on a reducing flame technique [121]. GR-CuNPs hybrids were used for the non-enzymatic detection of analytes specially glucose, and there is just one research that has investigated the GR-CuNPs hybrid as an enzyme immobilization platform. Huang et al. reported enzymatic biosensor for glucose detection. They dispersed GR nanocomposite in nafion and then dropped onto the GCE surface. CuNPs were electrodeposited onto modified electrode by cyclic voltammetry in solution containing $\mathrm{CuCl}_{2}$ and $\mathrm{NaCl}$ and after $\mathrm{CuNPs}$ electrodeposition, GOD was immobilized on the surface of modified electrode through electrostatic adsorption [98]. For this biosensor with the structure of GOD/CuNPs/GR-nafion/ GCE, the linear range, detection limit, and sensitivity were calculated $0.05 \times 10^{-3}-12 \times 10^{-3} \mathrm{M}, 5 \times 10^{-6} \mathrm{M}$, and 34 $\mu \mathrm{A} \mathrm{mM} \mathrm{m}^{-1} \mathrm{~cm}^{-2}$, respectively. The biosensor was stable for 20 days with $91.4 \%$ of its original response.

\section{Palladium nanoparticle}

Palladium nanoparticles (PdNPs) have high electron conductivity with small sizes (near to $1 \mathrm{~nm}$ ) [122]. In addition,

Table 4 NiO-GR-based electrochemical enzymatic biosensors

\begin{tabular}{|c|c|c|c|c|c|c|c|c|}
\hline $\begin{array}{l}\text { Biosensor struc- } \\
\text { ture }\end{array}$ & $\begin{array}{l}\text { Type of metallic } \\
\text { nanoparticle }\end{array}$ & $\begin{array}{l}\text { Used } \\
\text { enzyme or } \\
\text { protein }\end{array}$ & Analyte & Linear range $(\mathrm{M})$ & LOD (M) & Sensitivity & $\begin{array}{l}\text { Stabil- } \\
\text { ity } \\
\text { (days) }\end{array}$ & References \\
\hline $\begin{array}{l}\text { Nafion/Mb/NiO/ } \\
\text { GR/CILE }\end{array}$ & $\begin{array}{l}\text { Electrodeosited } \\
\mathrm{NiO}\end{array}$ & $\mathrm{Mb}$ & $\mathrm{H}_{2} \mathrm{O}_{2}$ & $\begin{array}{l}2.13 \times 10^{-6}- \\
248.2 \times 10^{-6}\end{array}$ & $0.71 \times 10^{-6}$ & - & 21 & [118] \\
\hline $\begin{array}{l}\text { Nafion/AChE- } \\
\text { Chit/NiO-CGR- } \\
\text { Nafion/GCE }\end{array}$ & $\mathrm{NiO}$ NPs & $\mathrm{AChE}$ & $\begin{array}{l}\text { Methyl parathion } \\
\text { Chlorpyrifos } \\
\text { Carbofuran }\end{array}$ & $\begin{array}{l}1.0 \times 10^{-13}-1 \times 10^{-10} \\
1.0 \times 10^{-10}-1 \times 10^{-8} \\
1.0 \times 10^{-12}-1 \times 10^{-10}\end{array}$ & $\begin{array}{l}5 \times 10^{-14} \\
5 \times 10^{-14} \\
5 \times 10^{-13}\end{array}$ & $\begin{array}{l}- \\
- \\
-\end{array}$ & 30 & [119] \\
\hline
\end{tabular}

$M b$ myoglobin, $C I L E$ carbon ionic liquid electrode, $C G R$ carboxylic graphene 
Pd and Pd-based nanostructures have tremendous catalytic efficiency and attracted considerable attention in different fields, and one of the most applications is glucose sensing in non-enzymatic sensors. For improving the performance of the glucose sensors and biosensors, PdNPs with low-dimensional carbon materials specially GR have been hybridized to get the advantage of the synergistic properties of surface compositions. Using GOD in electrochemical enzymatic biosensor, Zeng et al. fabricated a glucose biosensor by immobilizing GOD onto nanocomposites of PdNPs, chitosan, and GR (PdNPs/Chit-GR) through covalent crosslinking. First, they prepared the composite of Chit-GR, and after that, the composite was suspended and sonicated in ethylene glycol and water mixture. The ethylene glycol solution containing palladium chloride was added to this mixture and the $\mathrm{pH}$ was adjusted. For the immobilization of GOD onto the composite of PdNPs/Chit-GR, they used glutaric dialdehyde solution.

The resulting PdNPs/Chit-GR modified GCE displays electrocatalytic performance toward $\mathrm{H}_{2} \mathrm{O}_{2}$. The structure of biosensor was GOD/PdNPs/Chit-GR/GCE and the linear range, detection limit, and sensitivity for glucose detection were calculated $1.0 \times 10^{-6}-1.0 \times 10^{-3} \mathrm{M}, 0.2 \times 10^{-6} \mathrm{M}$, and $31.2 \mu \mathrm{A} \mathrm{mM}^{-1} \mathrm{~cm}^{-2}$, respectively. The biosensor stability was 21 days with losing $20 \%$ of its original response [123].

\section{Conclusion}

In the recent years, various nanoparticles have been used to construct electrochemical biosensors. GR and GO have been considered as attractive carbon materials due to their special properties including superior mechanical strength, electron transferring, low density, and high heat conductance. Also due to good conductivity, electrocatalytic ability, and biocompatibility related to nanoparticles of metal and metal oxide, the combination of GR and GO with metal nanoparticles particularly is useful for the application of them in the manufacture of electrochemical biosensors. The mixing of metal nanoparticles and carbon-based materials typically displays synergistic properties in immobilizing enzymes and electrocatalytic applications. The enzymatic biosensors have been reported based on GR-metal or metal oxide nanoparticles; however, the most applications are related to use AuNPs in GR and GO enzymatic biosensors. Considerable efforts are needed to use the hybrid of GR or GO with metal nanoparticles in immobilization of much more enzymes for recognition of numerous analytes due to catalytic properties, biocompatibility, and stability of these types of biosensors.

Open Access This article is distributed under the terms of the Creative Commons Attribution 4.0 International License (http://creativeco mmons.org/licenses/by/4.0/), which permits unrestricted use, distribution, and reproduction in any medium, provided you give appropriate credit to the original author(s) and the source, provide a link to the Creative Commons license, and indicate if changes were made.

\section{References}

1. Cipolatti, E.P., Silva, M.J.A., Klein, M., Feddern, V., Feltes, M.M.C., Oliveira, J.V., Ninow, J.L., de Oliveira, D.: Current status and trends in enzymatic nanoimmobilization. J. Mol. Catal. B Enzym. 99, 56-67 (2014)

2. Sharma, D., Kanchi, S., Sabela, M.I., Bisetty, K.: Insight into the biosensing of graphene oxide: present and future prospects. Arab. J. Chem. 9(2), 238-261 (2016)

3. Zhao, M., Gao, Y., Sun, J., Gao, F.: Mediatorless glucose biosensor and direct electron transfer type glucose/air biofuel cell enabled with carbon nanodots. Anal. Chem. 87(5), 2615-2622 (2015)

4. Miao, Z., Wang, P., Zhong, A., Yang, M., Xu, Q., Hao, S., Hu, X.: Development of a glucose biosensor based on electrodeposited gold nanoparticles-polyvinylpyrrolidone-polyaniline nanocomposites. J. Electroanal. Chem. 756, 153-160 (2015)

5. Das, P., Das, M., Chinnadayyala, S.R., Singha, I.M., Goswami, P.: Recent advances on developing 3rd generation enzyme electrode for biosensor applications. Biosens. Bioelectron. 79, 386397 (2016)

6. Baghayeri, M., Zare, E.N., Namadchian, M.: Direct electrochemistry and electrocatalysis of hemoglobin immobilized on biocompatible poly(styrene-alternative-maleic acid)/functionalized multi-wall carbon nanotubes blends. Sens. Actuators B Chem. 188, 227-234 (2013)

7. Luong, J.H.T., Glennon, J.D., Gedanken, A., Vashist, S.K.: Achievement and assessment of direct electron transfer of glucose oxidase in electrochemical biosensing using carbon nanotubes, graphene, and their nanocomposites. Microchim. Acta 184(2), 369-388 (2017)

8. Cheng, J., Zhang, M., Wu, G., Wang, X., Zhou, J., Cen, K.: Photoelectrocatalytic reduction of $\mathrm{CO}_{2}$ into chemicals using Pt-modified reduced graphene oxide combined with Pt-modified $\mathrm{TiO}_{2}$ nanotubes. Environ. Sci. Technol. 48(12), 7076-7084 (2014)

9. Putzbach, W., Ronkainen, N.: Immobilization techniques in the fabrication of nanomaterial-based electrochemical biosensors: a review. Sensors 13(4), 4811-4840 (2013)

10. Hwang, E.T., Gu, M.B.: Enzyme stabilization by nano/microsized hybrid materials. Eng. Life Sci. 13(1), 49-61 (2013)

11. Cipolatti, E.P., Valerio, A., Henriques, R.O., Moritz, D.E., Ninow, J.L., Freire, D.M.G., Manoel, E.A., Fernandez-Lafuente, R., de Oliveira, D.: Nanomaterials for biocatalyst immobilization-state of the art and future trends. RSC Adv. 6(106), 104675-104692 (2016)

12. Lawal, A.T.: Synthesis and utilisation of graphene for fabrication of electrochemical sensors. Talanta 131, 424-443 (2015)

13. Rao, C., Gopalakrishnan, K., Maitra, U.: Comparative study of potential applications of graphene, $\mathrm{MoS}_{2}$, and other two-dimensional materials in energy devices, sensors, and related areas. ACS Appl. Mater. Interfaces. 7(15), 7809-7832 (2015)

14. Butler, S.Z., Hollen, S.M., Cao, L., Cui, Y., Gupta, J.A., Gutiérrez, H.R., Heinz, T.F., Hong, S.S., Huang, J., Ismach, A.F.: Progress, challenges, and opportunities in two-dimensional materials beyond graphene. ACS Nano 7(4), 2898-2926 (2013)

15. Wang, X., Zhang, X.: Electrochemical co-reduction synthesis of graphene/nano-gold composites and its application to electrochemical glucose biosensor. Electrochim. Acta 112, 774-782 (2013) 
16. Georgakilas, V., Tiwari, J.N., Kemp, K.C., Perman, J.A., Bourlinos, A.B., Kim, K.S., Zboril, R.: Noncovalent functionalization of graphene and graphene oxide for energy materials, biosensing, catalytic, and biomedical applications. Chem. Rev. 116(9), 5464-5519 (2016)

17. Sun, J., Chen, Z., Yuan, L., Chen, Y., Ning, J., Liu, S., Ma, D., Song, X., Priydarshi, M.K., Bachmatiuk, A.: Direct chemicalvapor-deposition-fabricated, large-scale graphene glass with high carrier mobility and uniformity for touch panel applications. ACS Nano 10(12), 11136-11144 (2016)

18. Chen, A., Chatterjee, S.: Nanomaterials based electrochemical sensors for biomedical applications. Chem. Soc. Rev. 42(12), 5425-5438 (2013)

19. Zhu, C., Yang, G., Li, H., Du, D., Lin, Y.: Electrochemical sensors and biosensors based on nanomaterials and nanostructures. Anal. Chem. 87(1), 230-249 (2014)

20. Xu, M., Liang, T., Shi, M., Chen, H.: Graphene-like two-dimensional materials. Chem. Rev. 113(5), 3766-3798 (2013)

21. Gupta, A., Sakthivel, T., Seal, S.: Recent development in 2D materials beyond graphene. Prog. Mater Sci. 73, 44-126 (2015)

22. Yang, G., Zhu, C., Du, D., Zhu, J., Lin, Y.: Graphene-like twodimensional layered nanomaterials: applications in biosensors and nanomedicine. Nanoscale 7(34), 14217-14231 (2015)

23. Varghese, S.S., Lonkar, S., Singh, K., Swaminathan, S., Abdala, A.: Recent advances in graphene based gas sensors. Sens. Actuators B Chem. 218, 160-183 (2015)

24. Mao, S., Lu, G., Chen, J.: Nanocarbon-based gas sensors: progress and challenges. J. Mater. Chem. A 2(16), 5573-5579 (2014)

25. Ferrari, A.C., Bonaccorso, F., Fal'Ko, V., Novoselov, K.S., Roche, S., Bøggild, P., Borini, S., Koppens, F.H., Palermo, V., Pugno, N.: Science and technology roadmap for graphene, related two-dimensional crystals, and hybrid systems. Nanoscale 7(11), 4598-4810 (2015)

26. Arjmandi-Tash, H., Belyaeva, L.A., Schneider, G.F.: Single molecule detection with graphene and other two-dimensional materials: nanopores and beyond. Chem. Soc. Rev. 45(3), 476-493 (2016)

27. Singh, M., Holzinger, M., Tabrizian, M., Winters, S.A., Berner, N.C., Cosnier, S., Duesberg, G.S.: Noncovalently functionalized monolayer graphene for sensitivity enhancement of surface plasmon resonance immunosensors. J. Am. Chem. Soc. 137(8), 2800-2803 (2015)

28. Kostarelos, K., Novoselov, K.S.: Graphene devices for life. Nat. Nanotechnol. 9(10), 744-745 (2014)

29. Zhang, Y., Bai, X., Wang, X., Shiu, K.-K., Zhu, Y., Jiang, H.: Highly sensitive graphene-Pt nanocomposites amperometric biosensor and its application in living cell $\mathrm{H}_{2} \mathrm{O}_{2}$ detection. Anal. Chem. 86(19), 9459-9465 (2014)

30. Sadeghinezhad, E., Mehrali, M., Saidur, R., Mehrali, M., Tahan Latibari, S., Akhiani, A.R., Metselaar, H.S.C.: A comprehensive review on graphene nanofluids: Recent research, development and applications. Energy Convers. Manag. 111, 466-487 (2016)

31. Goenka, S., Sant, V., Sant, S.: Graphene-based nanomaterials for drug delivery and tissue engineering. J. Control. Release 173, 75-88 (2014)

32. Arnold, H.N., Cress, C.D., McMorrow, J.J., Schmucker, S.W., Sangwan, V.K., Jaber-Ansari, L., Kumar, R., Puntambekar, K.P., Luck, K.A., Marks, T.J.: Tunable radiation response in hybrid organic-inorganic gate dielectrics for low-voltage graphene electronics. ACS Appl. Mater. Interfaces. 8(8), 50585064 (2016)

33. Lin, Z., Taberna, P.-L., Simon, P.: Graphene-based supercapacitors using eutectic ionic liquid mixture electrolyte. Electrochim. Acta 206, 446-451 (2016)
34. Liu, J., Zheng, Q., Goodman, M.D., Zhu, H., Kim, J., Krueger, N.A., Ning, H., Huang, X., Liu, J., Terrones, M.: Lithium-ion batteries: graphene sandwiched mesostructured Li-ion battery electrodes (Adv. Mater. 35/2016). Adv. Mater. 28(35), 7695 (2016)

35. Palaniselvam, T., Kashyap, V., Bhange, S.N., Baek, J.B., Kurungot, S.: Nanoporous Graphene enriched with $\mathrm{Fe} / \mathrm{Co}-\mathrm{N}$ active sites as a promising oxygen reduction electrocatalyst for anion exchange membrane fuel cells. Adv. Funct. Mater. 26(13), 2150$2162(2016)$

36. Sun, J., Xie, X., Bi, H., Jia, H., Zhu, C., Wan, N., Huang, J., Nie, M., Li, D., Sun, L.: Solution-assisted ultrafast transfer of graphene-based thin films for solar cells and humidity sensors. Nanotechnology 28(13), 134004 (2017)

37. Fartas, F.M., Abdullah, J., Yusof, N.A., Sulaiman, Y., Saiman, M.I.: Biosensor based on tyrosinase immobilized on graphenedecorated gold nanoparticle/chitosan for phenolic detection in aqueous. Sensors 17(5), 1132-1146 (2017)

38. Zan, X., Bai, H., Wang, C., Zhao, F., Duan, H.: Graphene paper decorated with a $2 \mathrm{D}$ array of dendritic platinum nanoparticles for ultrasensitive electrochemical detection of dopamine secreted by live cells. Chem. Eur. J. 22(5), 5204-5210 (2016)

39. Zhou, Y., Cao, J., Zhao, J., Xie, Y., Fei, J., Cai, Y.: Temperatureresponsive amperometric $\mathrm{H}_{2} \mathrm{O}_{2}$ biosensor using a composite film consisting of poly ( $N$-isopropylacrylamide)- $b$-poly (2-acrylamidoethyl benzoate), graphene oxide and hemoglobin. Microchim. Acta 183(9), 2501-2508 (2016)

40. Aslan, S., Anik, Ü.: Microbial glucose biosensors based on glassy carbon paste electrodes modified with Gluconobacter oxydans and graphene oxide or graphene-platinum hybrid nanoparticles. Microchim. Acta 183(1), 73-81 (2016)

41. Breczko, J., Regulska, E., Basa, A., Baran, M., Winkler, K., Plonska-Brzezinska, M.E.: Three-component EC-SPR biosensor based on graphene oxide, $\mathrm{SiO}_{2}$ and gold nanoparticles in NADH determination. ECS J. Solid State Sci. Technol. 5(8), M3018-M3025 (2016)

42. Abellán-Llobregat, A., Vidal, L., Rodríguez-Amaro, R., Berenguer-Murcia, Á., Canals, A., Morallon, E.: Au-IDA microelectrodes modified with Au-doped graphene oxide for the simultaneous determination of uric acid and ascorbic acid in urine samples. Electrochim. Acta 227, 275-284 (2017)

43. Chen, J., Zhang, Y., Zhang, M., Yao, B., Li, Y., Huang, L., Li, C., Shi, G.: Water-enhanced oxidation of graphite to graphene oxide with controlled species of oxygenated groups. Chem. Sci. 7(3), 1874-1881 (2016)

44. Kang, J.H., Kim, T., Choi, J., Park, J., Kim, Y.S., Chang, M.S., Jung, H., Park, K.T., Yang, S.J., Park, C.R.: Hidden second oxidation step of Hummers method. Chem. Mater. 28(3), 756-764 (2016)

45. Pattnaik, S., Swain, K., Lin, Z.: Graphene and graphene-based nanocomposites: biomedical applications and biosafety. J. Mater. Chem. B 4(48), 7813-7831 (2016)

46. Yan, H., Yang, H., Li, A., Cheng, R.: pH-tunable surface charge of chitosan/graphene oxide composite adsorbent for efficient removal of multiple pollutants from water. Chem. Eng. J. 284, 1397-1405 (2016)

47. Randviir, E.P., Brownson, D.A., Banks, C.E.: A decade of graphene research: production, applications and outlook. Mater. Today 17(9), 426-432 (2014)

48. Zhang, Y., Zhang, L., Zhou, C.: Review of chemical vapor deposition of graphene and related applications. Acc. Chem. Res. 46(10), 2329-2339 (2013)

49. Parvez, K., Wu, Z.-S., Li, R., Liu, X., Graf, R., Feng, X., Müllen, $\mathrm{K}$. : Exfoliation of graphite into graphene in aqueous solutions of inorganic salts. J. Am. Chem. Soc. 136(16), 6083-6091 (2014) 
50. Ciesielski, A., Samorì, P.: Graphene via sonication assisted liquid-phase exfoliation. Chem. Soc. Rev. 43(1), 381-398 (2014)

51. Carbone, M., Gorton, L., Antiochia, R.: An overview of the latest graphene-based sensors for glucose detection: the effects of graphene defects. Electroanalysis 27(1), 16-31 (2015)

52. Shen, M., Wu, C., Lin, C., Fan, G., Jin, Y., Zhang, Z., Li, C., Jia, W.: Facile solvothermal synthesis of mesostructured chitosancoated $\mathrm{Fe}_{3} \mathrm{O}_{4}$ nanoparticles and its further modification with folic acid for improving targeted drug delivery. NANO 9(7), 1450081 (2014)

53. Saleem, H., Edathil, A., Ncube, T., Pokhrel, J., Khoori, S., Abraham, A., Mittal, V.: Mechanical and thermal properties of thermoset-graphene nanocomposites. Macromol. Mater. Eng. 301(3), 231-259 (2016)

54. Hwang, S.-H., Kang, D., Ruoff, R.S., Shin, H.S., Park, Y.-B.: Poly (vinyl alcohol) reinforced and toughened with poly (dopamine)-treated graphene oxide, and its use for humidity sensing. ACS Nano 8(7), 6739-6747 (2014)

55. Kim, N.H., Kuila, T., Lee, J.H.: Simultaneous reduction, functionalization and stitching of graphene oxide with ethylenediamine for composites application. J. Mater. Chem. A 1(4), 1349-1358 (2013)

56. Kumar, S., Raj, S., Jain, S., Chatterjee, K.: Multifunctional biodegradable polymer nanocomposite incorporating graphene-silver hybrid for biomedical applications. Mater. Des. 108, 319-332 (2016)

57. Uddin, M.E., Kuila, T., Nayak, G.C., Kim, N.H., Ku, B.-C., Lee, J.H.: Effects of various surfactants on the dispersion stability and electrical conductivity of surface modified graphene. J. Alloy. Compd. 562, 134-142 (2013)

58. Layek, R.K., Nandi, A.K.: A review on synthesis and properties of polymer functionalized graphene. Polymer 54(19), 5087-5103 (2013)

59. Urbanova, V., Magro, M., Gedanken, A., Baratella, D., Vianello, F., Zboril, R.: Nanocrystalline iron oxides, composites, and related materials as a platform for electrochemical, magnetic, and chemical biosensors. Chem. Mater. 26(23), 6653-6673 (2014)

60. Bridewell, V.L., Karwacki, C.J., Kamat, P.V.: Electrocatalytic sensing with reduced graphene oxide: electron shuttling between redox couples anchored on a 2-D surface. ACS Sens. 1(10), 1203-1207 (2016)

61. Huang, K.-J., Li, J., Wu, Y.-Y., Liu, Y.-M.: Amperometric immunobiosensor for $\alpha$-fetoprotein using Au nanoparticles/chitosan/ $\mathrm{TiO}_{2}$-graphene composite based platform. Bioelectrochemistry 90, 18-23 (2013)

62. Lepinay, S., Staff, A., Ianoul, A., Albert, J.: Improved detection limits of protein optical fiber biosensors coated with gold nanoparticles. Biosens. Bioelectron. 52, 337-344 (2014)

63. Devi, R.V., Doble, M., Verma, R.S.: Nanomaterials for early detection of cancer biomarker with special emphasis on gold nanoparticles in immunoassays/sensors. Biosens. Bioelectron. 68, 688-698 (2015)

64. Polavarapu, L., Pérez-Juste, J., Xu, Q.-H., Liz-Marzán, L.M.: Optical sensing of biological, chemical and ionic species through aggregation of plasmonic nanoparticles. J. Mater. Chem. C 2(36), 7460-7476 (2014)

65. Yusoff, N., Pandikumar, A., Ramaraj, R., Lim, H.N., Huang, N.M.: Gold nanoparticle based optical and electrochemical sensing of dopamine. Microchim. Acta 182(13-14), 2091$2114(2015)$

66. Yola, M.L., Eren, T., Atar, N.: A sensitive molecular imprinted electrochemical sensor based on gold nanoparticles decorated graphene oxide: application to selective determination of tyrosine in milk. Sens. Actuators B Chem. 210, 149-157 (2015)

67. Zhu, L., Xu, L., Tan, L., Tan, H., Yang, S., Yao, S.: Direct electrochemistry of cholesterol oxidase immobilized on gold nanoparticles-decorated multiwalled carbon nanotubes and cholesterol sensing. Talanta 106, 192-199 (2013)

68. Elshafey, R., Tavares, A.C., Siaj, M., Zourob, M.: Electrochemical impedance immunosensor based on gold nanoparticlesprotein $\mathrm{G}$ for the detection of cancer marker epidermal growth factor receptor in human plasma and brain tissue. Biosens. Bioelectron. 50, 143-149 (2013)

69. Luo, P., Liu, Y., Xia, Y., Xu, H., Xie, G.: Aptamer biosensor for sensitive detection of toxin A of Clostridium difficile using gold nanoparticles synthesized by Bacillus stearothermophilus. Biosens. Bioelectron. 54, 217-221 (2014)

70. Feng, D., Lu, X., Dong, X., Ling, Y., Zhang, Y.: Label-free electrochemical immunosensor for the carcinoembryonic antigen using a glassy carbon electrode modified with electrodeposited Prussian Blue, a graphene and carbon nanotube assembly and an antibody immobilized on gold nanoparticles. Microchim. Acta 180(9-10), 767-774 (2013)

71. Gotti, G., Fajerwerg, K., Evrard, D., Gros, P.: Electrodeposited gold nanoparticles on glassy carbon: correlation between nanoparticles characteristics and oxygen reduction kinetics in neutral media. Electrochim. Acta 128, 412-419 (2014)

72. Ma, H., Sun, J., Zhang, Y., Bian, C., Xia, S., Zhen, T.: Labelfree immunosensor based on one-step electrodeposition of chitosan-gold nanoparticles biocompatible film on Au microelectrode for determination of aflatoxin B1 in maize. Biosens. Bioelectron. 80, 222-229 (2016)

73. Sabury, S., Kazemi, S.H., Sharif, F.: Graphene-gold nanoparticle composite: application as a good scaffold for construction of glucose oxidase biosensor. Mater. Sci. Eng. C 49, 297-304 (2015)

74. Xue, C., Gao, M., Xue, Y., Zhu, L., Dai, L., Urbas, A., Li, Q.: Building 3D layer-by-layer graphene-gold nanoparticle hybrid architecture with tunable interlayer distance. J. Phys. Chem. C 118(28), 15332-15338 (2014)

75. Dutta, S., Ray, C., Mallick, S., Sarkar, S., Roy, A., Pal, T.: Au@ Pd core-shell nanoparticles-decorated reduced graphene oxide: a highly sensitive and selective platform for electrochemical detection of hydrazine. RSC Adv. 5(64), 51690-51700 (2015)

76. Henry, A.L., Plumejeau, S., Heux, L., Louvain, N., Monconduit, L., Stievano, L., Boury, B.: Conversion of nanocellulose aerogel into $\mathrm{TiO}_{2}$ and $\mathrm{TiO}_{2} @ \mathrm{C}$ nano-thorns by direct anhydrous mineralization with $\mathrm{TiCl}_{4}$. Evaluation of electrochemical properties in Li batteries. ACS Appl. Mater. Interfaces 7(27), 14584-14592 (2015)

77. Zhou, K., Zhu, Y., Yang, X., Luo, J., Li, C., Luan, S.: A novel hydrogen peroxide biosensor based on Au-graphene-HRP-chitosan biocomposites. Electrochim. Acta 55(9), 3055-3060 (2010)

78. Sheng, Q., Wang, M., Zheng, J.: A novel hydrogen peroxide biosensor based on enzymatically induced deposition of polyaniline on the functionalized graphene-carbon nanotube hybrid materials. Sens. Actuators B Chem. 160(1), 1070-1077 (2011)

79. Zhiguo, G., Shuping, Y., Zaijun, L., Xiulan, S., Guangli, W., Yinjun, F., Junkang, L.: An ultrasensitive hydrogen peroxide biosensor based on electrocatalytic synergy of graphene-gold nanocomposite, CdTe-CdS core-shell quantum dots and gold nanoparticles. Anal. Chim. Acta 701(1), 75-80 (2011)

80. Shan, C., Yang, H., Han, D., Zhang, Q., Ivaska, A., Niu, L.: Graphene/AuNPs/chitosan nanocomposites film for glucose biosensing. Biosens. Bioelectron. 25(5), 1070-1074 (2010)

81. Xu, Q., Gu, S.-X., Jin, L., Zhou, Y.-E., Yang, Z., Wang, W., Hu, $X$.: Graphene/polyaniline/gold nanoparticles nanocomposite for the direct electron transfer of glucose oxidase and glucose biosensing. Sens. Actuators B Chem. 190, 562-569 (2014)

82. Fang, Y., Zhang, D., Guo, Y., Guo, Y., Chen, Q.: Simple one-pot preparation of chitosan-reduced graphene oxide-Au nanoparticles hybrids for glucose sensing. Sens. Actuators B Chem. 221, 265-272 (2015) 
83. Oliveira, T.M.B.F., Barroso, M.F., Morais, S., Araújo, M., Freire, C., de Lima-Neto, P., Correia, A.N., Oliveira, M.B.P.P., DelerueMatos, C.: Sensitive bi-enzymatic biosensor based on polyphenoloxidases-gold nanoparticles-chitosan hybrid film-graphene doped carbon paste electrode for carbamates detection. Bioelectrochemistry 98, 20-29 (2014)

84. Pan, D., Gu, Y., Lan, H., Sun, Y., Gao, H.: Functional graphenegold nano-composite fabricated electrochemical biosensor for direct and rapid detection of bisphenol A. Anal. Chim. Acta 853, 297-302 (2015)

85. Zhao, H., Ji, X., Wang, B., Wang, N., Li, X., Ni, R., Ren, J.: An ultra-sensitive acetylcholinesterase biosensor based on reduced graphene oxide-Au nanoparticles- $\beta$-cyclodextrin/Prussian bluechitosan nanocomposites for organophosphorus pesticides detection. Biosens. Bioelectron. 65, 23-30 (2015)

86. Pasang, T., Namratha, K., Parvin, T., Ranganathaiah, C., Byrappa, $\mathrm{K}$.: Tuning of band gap in $\mathrm{TiO}_{2}$ and $\mathrm{ZnO}$ nanoparticles by selective doping for photocatalytic applications. Mater. Res. Innov. 19(1), 73-80 (2015)

87. Kapilashrami, M., Zhang, Y., Liu, Y.-S., Hagfeldt, A., Guo, J.: Probing the optical property and electronic structure of $\mathrm{TiO}_{2}$ nanomaterials for renewable energy applications. Chem. Rev. 114(19), 9662-9707 (2014)

88. Ghosh, S., Das, A.: Modified titanium oxide $\left(\mathrm{TiO}_{2}\right)$ nanocomposites and its array of applications: a review. Toxicol. Environ. Chem. 97(5), 491-514 (2015)

89. Liu, J., Song, K., van Aken, P.A., Maier, J., Yu, Y.: Self-supported $\mathrm{Li}_{4} \mathrm{Ti}_{5} \mathrm{O}_{12}-\mathrm{C}$ nanotube arrays as high-rate and long-life anode materials for flexible Li-ion batteries. Nano Lett. 14(5), 2597-2603 (2014)

90. Madian, M., Giebeler, L., Klose, M., Jaumann, T., Uhlemann, M., Gebert, A., Oswald, S., Ismail, N., Eychmuller, A., Eckert, J.: Self-organized $\mathrm{TiO}_{2} / \mathrm{CoO}$ nanotubes as potential anode materials for lithium ion batteries. ACS Sustain. Chem. Eng. 3(5), 909-919 (2015)

91. Kim, S.-J., Cho, Y.K., Seok, J., Lee, N.-S., Son, B., Lee, J.W., Baik, J.M., Lee, C., Lee, Y., Kim, M.H.: Highly branched $\mathrm{RuO}_{2}$ nanoneedles on electrospun $\mathrm{TiO}_{2}$ nanofibers as an efficient electrocatalytic platform. ACS Appl. Mater. Interfaces. 7(28), 15321-15330 (2015)

92. Ahmad, K., Mohammad, A., Rajak, R., Mobin, S.M.: Construction of $\mathrm{TiO}_{2}$ nanosheets modified glassy carbon electrode (GCE/ $\mathrm{TiO}_{2}$ ) for the detection of hydrazine. Mater. Res. Express 3(7), 074005 (2016)

93. Feng, C., Xu, G., Liu, H., Lv, J., Zheng, Z., Wu, Y.: Facile fabrication of $\mathrm{Pt} / \mathrm{graphene} / \mathrm{TiO}_{2}$ NTAs based enzyme sensor for glucose detection. J. Electrochem. Soc. 161(1), B1-B8 (2014)

94. Leonardi, S.G., Aloisio, D., Donato, N., Russo, P.A., Ferro, M.C., Pinna, N., Neri, G.: Amperometric sensing of $\mathrm{H}_{2} \mathrm{O}_{2}$ using $\mathrm{Pt}-\mathrm{TiO}_{2} /$ reduced graphene oxide nanocomposites. ChemElectroChem 1(3), 617-624 (2014)

95. Hong, J., Zhao, Y.-X., Xiao, B.-L., Moosavi-Movahedi, A.A., Ghourchian, H., Sheibani, N.: Direct electrochemistry of hemoglobin immobilized on a functionalized multi-walled carbon nanotubes and gold nanoparticles nanocomplex-modified glassy carbon electrode. Sensors 13(7), 8595-8611 (2013)

96. Zhu, J., Liu, X., Wang, X., Huo, X., Yan, R.: Preparation of polyaniline- $\mathrm{TiO}_{2}$ nanotube composite for the development of electrochemical biosensors. Sens. Actuators B Chem. 221, 450-457 (2015)

97. Wang, J.T.-W., Ball, J.M., Barea, E.M., Abate, A., AlexanderWebber, J.A., Huang, J., Saliba, M., Mora-Sero, I., Bisquert, J., Snaith, H.J.: Low-temperature processed electron collection layers of graphene/ $\mathrm{TiO}_{2}$ nanocomposites in thin film perovskite solar cells. Nano Lett. 14(2), 724-730 (2013)
98. Huang, K.-J., Wang, L., Li, J., Gan, T., Liu, Y.-M.: Glassy carbon electrode modified with glucose oxidase-graphene-nanocopper composite film for glucose sensing. Measurement 46(1), 378-383 (2013)

99. Yang, N., Liu, Y., Wen, H., Tang, Z., Zhao, H., Li, Y., Wang, D.: Photocatalytic properties of graphdiyne and graphene modified $\mathrm{TiO}_{2}$ : from theory to experiment. ACS Nano 7(2), 1504-1512 (2013)

100. Sun, J.-Y., Huang, K.-J., Zhao, S.-F., Fan, Y., Wu, Z.-W.: Direct electrochemistry and electrocatalysis of hemoglobin on chitosanroom temperature ionic liquid- $\mathrm{TiO}_{2}$-graphene nanocomposite film modified electrode. Bioelectrochemistry 82(2), 125-130 (2011)

101. Iqbal, A., Iqbal, K., Li, B., Gong, D., Qin, W.: Recent advances in iron nanoparticles: preparation, properties, biological and environmental application. J. Nanosci. Nanotechnol. 17(7), 4386-4409 (2017)

102. Chatterjee, K., Sarkar, S., Rao, K.J., Paria, S.: Core/shell nanoparticles in biomedical applications. Adv. Colloid Interfaces Sci. 209, 8-39 (2014)

103. Yang, C., Bian, X., Qin, J., Zhao, X., Zhang, K., Bai, Y.: An investigation of a viscosity-magnetic field hysteretic effect in nano-ferrofluid. J. Mol. Liq. 196, 357-362 (2014)

104. Zhao, L., Gao, M., Yue, W., Jiang, Y., Wang, Y., Ren, Y., Hu, F.: Sandwich-structured graphene- $\mathrm{Fe}_{3} \mathrm{O}_{4} @$ Carbon nanocomposites for high-performance lithium-ion batteries. ACS Appl. Mater. Interfaces 7(18), 9709-9715 (2015)

105. Yadav, R.S., Sharma, V., Kuanr, B.K.: Magnetic nanoparticles; synthesis, characterization and application as contrast agent in magnetic resonance imaging (MRI). Adv. Sci. Lett. 20(7-9), 1548-1550 (2014)

106. Gan, Q., Zhu, J., Yuan, Y., Liu, C.: pH-responsive $\mathrm{Fe}_{3} \mathrm{O}_{4}$ nanoparticles-capped mesoporous silica supports for protein delivery. J. Nanosci. Nanotechnol. 16(6), 5470-5479 (2016)

107. Nasrollahzadeh, M., Sajadi, S.M., Rostami-Vartooni, A., Khalaj, M.: Green synthesis of $\mathrm{Pd} / \mathrm{Fe}_{3} \mathrm{O}_{4}$ nanoparticles using Euphorbia condylocarpa $\mathrm{M}$. bieb root extract and their catalytic applications as magnetically recoverable and stable recyclable catalysts for the phosphine-free Sonogashira and Suzuki coupling reactions. J. Mol. Catal. A Chem. 396, 31-39 (2015)

108. Chauhan, N., Narang, J., Jain, U.: Amperometric acetylcholinesterase biosensor for pesticides monitoring utilising iron oxide nanoparticles and poly(indole-5-carboxylic acid). J. Exp. Nanosci. 11(2), 111-122 (2016)

109. Gu, T., Wang, J., Xia, H., Wang, S., Yu, X.: Direct electrochemistry and electrocatalysis of horseradish peroxidase immobilized in a DNA/chitosan- $\mathrm{Fe}_{3} \mathrm{O}_{4}$ magnetic nanoparticle bio-complex film. Materials 7(2), 1069-1083 (2014)

110. Zhu, S., Guo, J., Dong, J., Cui, Z., Lu, T., Zhu, C., Zhang, D., Ma, $\mathrm{J}$.: Sonochemical fabrication of $\mathrm{Fe}_{3} \mathrm{O}_{4}$ nanoparticles on reduced graphene oxide for biosensors. Ultrason. Sonochem. 20(3), 872880 (2013)

111. Zhou, K., Zhu, Y., Yang, X., Li, C.: Preparation and application of mediator-free $\mathrm{H}_{2} \mathrm{O}_{2}$ biosensors of graphene- $\mathrm{Fe}_{3} \mathrm{O}_{4}$ composites. Electroanalysis 23(4), 862-869 (2011)

112. Hsieh, C.-T., Lin, J.-Y., Mo, C.-Y.: Improved storage capacity and rate capability of $\mathrm{Fe}_{3} \mathrm{O}_{4}$-graphene anodes for lithium-ion batteries. Electrochim. Acta 58, 119-124 (2011)

113. Xin, Y., Fu-bing, X., Hong-wei, L., Feng, W., Di-zhao, C., Zhaoyang, W.: A novel $\mathrm{H}_{2} \mathrm{O}_{2}$ biosensor based on $\mathrm{Fe}_{3} \mathrm{O}_{4}-\mathrm{Au}$ magnetic nanoparticles coated horseradish peroxidase and graphene sheets-Nafion film modified screen-printed carbon electrode. Electrochim. Acta 109, 750-755 (2013)

114. Teymourian, H., Salimi, A., Khezrian, S.: $\mathrm{Fe}_{3} \mathrm{O}_{4}$ magnetic nanoparticles/reduced graphene oxide nanosheets as a novel 
electrochemical and bioelectrochemical sensing platform. Biosens. Bioelectron. 49, 1-8 (2013)

115. Wang, B., Li, S., Liu, J., Yu, M.: Preparation of nickel nanoparticle/graphene composites for non-enzymatic electrochemical glucose biosensor applications. Mater. Res. Bull. 49, 521-524 (2014)

116. Nancy, T.E.M., Kumary, V.A.: Synergistic electrocatalytic effect of graphene/nickel hydroxide composite for the simultaneous electrochemical determination of ascorbic acid, dopamine and uric acid. Electrochim. Acta 133, 233-240 (2014)

117. Rahman, M.M., Ahammad, A., Jin, J.-H., Ahn, S.J., Lee, J.-J.: A comprehensive review of glucose biosensors based on nanostructured metal-oxides. Sensors 10(5), 4855-4886 (2010)

118. Sun, W., Gong, S., Deng, Y., Li, T., Cheng, Y., Wang, W., Wang, L.: Electrodeposited nickel oxide and graphene modified carbon ionic liquid electrode for electrochemical myoglobin biosensor. Thin Solid Films 562, 653-658 (2014)

119. Yang, L., Wang, G., Liu, Y., Wang, M.: Development of a biosensor based on immobilization of acetylcholinesterase on $\mathrm{NiO}$ nanoparticles-carboxylic graphene-nafion modified electrode for detection of pesticides. Talanta 113, 135-141 (2013)
120. Wang, Y., Wei, W., Zeng, J., Liu, X., Zeng, X.: Fabrication of a copper nanoparticle/chitosan/carbon nanotube-modified glassy carbon electrode for electrochemical sensing of hydrogen peroxide and glucose. Microchim. Acta 160(1-2), 253-260 (2008)

121. Chen, Q., Zhang, L., Chen, G.: Facile preparation of graphenecopper nanoparticle composite by in situ chemical reduction for electrochemical sensing of carbohydrates. Anal. Chem. 84(1), 171-178 (2012)

122. Baccar, H., Ktari, T., Abdelghani, A.: Functionalized palladium nanoparticles for hydrogen peroxide biosensor. Int. J. Electrochem. 6, 4 (2011)

123. Zeng, Q., Cheng, J.-S., Liu, X.-F., Bai, H.-T., Jiang, J.-H.: Palladium nanoparticle/chitosan-grafted graphene nanocomposites for construction of a glucose biosensor. Biosens. Bioelectron. 26(8), 3456-3463 (2011)

Publisher's Note Springer Nature remains neutral with regard to jurisdictional claims in published maps and institutional affiliations. 